\title{
Macroeconomic Aspects of Entrepreneurship in Central- East Europe - A Comment
}

\author{
Johannes Stephan, Institut für Wirtschaftsforschung, Halle
}

When addressing the topic of macroeconomic aspects of entrepreneurship in transition economies, the usual and orthodox perception is that the creation of markets via privatisation and liberalisation are the two paramount conditions for entrepreneurs to engage in the market. Unless private ownership in productive capital is guaranteed and the private entrepreneur is allowed to pocket profits arising from his investment (into what he perceived as an opportunity), investment will not take place. Liberalisation of prices allows the entrepreneur to recognise opportunities, i.e. when market-determined prices are higher than the entrepreneur's cost calculations. External liberalisation for foreign trade installs an undistorted structure of prices and provides the entrepreneur additionally with the opportunity to market his products abroad or compete with imports by taking advantage of his home economy's comparative advantages.

Hölscher's analysis, however, holds that next to these two aspects, a further set of macroeconomic 'conditio sine qua non' necessarily have to be fulfilled to make potential entrepreneurs actually invest. Part of these additional conditions are interestingly in clear conflict with the above sketched orthodox categories. His analysis features an interesting approach by assessing (exclusively monetary) market constellations of monetary stability (i.e. inflation and what is treated rather short and implicitly in his analysis is monetary policy and the real interest rate) and the exchange rate or rather the expectations of entrepreneurs on the further development of the exchange rate.

Hölscher's additional conditions can be broadly summarised as first a constellation in which the ex-ante (real) interest rate remains lower than profits expected by the entrepreneur. Unless this constellation is met, the economy could be faced with the depressing scenario of stagflation. Whilst empirical research into the correlation between interest rates and investment are ambiguous and do not clearly support the intuition that low interest rates support investment, the measure of entrepreneurial profit expectations completely escapes measurability, so that the intuition used by Hölscher cannot be tested. In support of Hölscher's case, it is additionally perceivable, however, that with rising interest rates, investment projects which are being granted with external funding, i.e. credit, tend to be more risk-prone. This would raise the chances of 
investment projects to fail ('adverse credit selection', Stiglitz and Weiss). But not all investment in transition economies can be expected to be credit-financed. In particular during the first years of systemic transformations, a functioning credit market did not exist. It could also be assumed that at least in the early stages of transformation, investment projects were largely financed by retained earnings of existing enterprises and later by foreign investors. Other research into financial market development in transition economies suggests that bank crediting of firms was rather independent of interest rate and profit expectation levels. (Mis)allocation was largely guided by the 'bad asset' problem, i.e. existing stocks. Furthermore, Hölscher's analysis leaves open what economic policy in transition economies can do to disinflate, if the interest rate is not to reach levels which suppress opportunities of potential entrepreneurs.

The second constellation put forward by Hölscher's analysis envisages expectations of exchange rate revaluation on behalf of the entrepreneur which, however, are not fulfilled. This constellation calls for anything from 'semiliberalisation' (decreasing and selective protection) up to outright protection (Semenkov), and currency undervaluation is defined as export surplus of the balance of trade. Here, the author does acknowledge that this condition "challenges the widespread liberalisation doctrine" (p. _ 7 in my print-out). In terms of the above outlined orthodox view on external liberalisation, export and import substituting opportunities are artificially improved and hence feature a less efficient allocation of resources between economies. Furthermore, any measure of selective protection will have a distorting effect on the structure of prices and hence the set of opportunities signalled to the entrepreneur: investment projects might turn out to be not viable long-term, i.e. as soon as protection in this sector is removed and a comparative advantage does not (yet) exist. In accordance with Hölscher, in terms of catch-up development, such reflections on the efficiency of allocation will prove to be of less significance than the depressing effects of transformational recession and widespread importpenetration by western producers. In terms of entrepreneurial aspects, a distorted price structure (between two economies as well as within one economy) might well turn out to be relevant in the medium to long term.

Hölscher's analysis could be carried further by an enquiry into emerging entrepreneurial activities via the opportunities arising from the privatisation, the dismantling of vertically integrated firms and the immense decline in economic activity during transformational recession, as well as structural change and the redirection of foreign trade. Privatisation of state-owned enterprises and their subsequent dismantling opened formidable opportunities for entrepreneurs (e.g. the so-called management buy-outs, or buy-ins) as did supply-shortages arising from the closure of productive economic entities. The fundamental change in the 
structural composition of domestic production (between branches) which had been induced by external liberalisation and the redirection of foreign trade away from markets in the East to such in the West has set entrepreneurial resources free in some branches whilst opening new opportunities, a scenario Hölscher accurately terms 'Schumpeterian creative destruction'. Also of macroeconomic provenience, such structural considerations might well prove to be just as enlightening in assessing the world faced by entrepreneurs in transition economies in Central East Europe. 